\title{
Centripetális és centrifugális erők az Európai Unióban*
}

\author{
Szapáry György
}

A 21. század gazdasági válságai kihívás elé állították az Európai Unió egységességét. A kezdeti erős centripetális erőket új, nem várt centrifugális erők kezdték el gyengíteni. Vajon mit hoz a jövő az Európai Unió számára? Hogy tud szembenézni a nem várt kihívásokkal? A jelenleg legfontosabb megosztó, széthúzó erők az EU-n belül a tömeges migráció kezelése, az EU költségvetése körül kialakult viták, az egységes külpolitika hiánya és a szuverenitás versus föderalizmus kérdése. Az esszé ezeket a kérdéseket veszi sorba, ugyanis nem létezhet erős, befolyásos, egységes Európa a migrációs válságra minden tagország által elfogadott megoldás nélkül, egy jobban összehangolt költségvetési és külpolitika nélkül, valamint a nemzetállamok szuverenitását biztosító kimondott és egységesen elfogadott értelmezés nélkül. Ezek a témák valószínü még éveken át megosztó, centrifugális erőként fogják nehezíteni az európai integráció elöre vitelét, de szükséges ezekröl beszélni, hogy fel lehessen ismerni a legfontosabb teendőket.

Journal of Economic Literature (JEL) kódok: N14, F53, H61, H63, H77

Kulcsszavak: Európai Unió, migráció, EU költségvetés, külpolitika, szuverenitás

\section{A kezdeti centripetális erők}

1945-ben a második világháború egy romokban heverő Európát hagyott maga után. A több évig tartó háborúskodás sok millió árvát, éhező, otthonukat elhagyni kényszerülő állampolgárt, lebombázott városokat hagyott maga után. Az emberek mind a békét szomjazták. Ez a kollektív cél volt az európai integrációt elindító legfontosabb összetartó erő. Bár a kontinensen ismét béke honolt, Európa kettészakadt egy, a szovjet kommunista diktatúra zsarnoksága alá kényszerített Kelet-Európára és egy erősödő, gazdaságilag gyorsan fejlődő, demokratikus Nyugat-Európára.

Robert Schuman javaslatára létrehozták 1951-ben az Európai Szén- és Acélközösséget, hogy Schuman szavaival élve, a háborút ne csak elképzelhetetlenné, hanem fizikailag is lehetetlenné tegyék, ezzel ellehetetlenítve a fegyverkezést

* A jelen kiadványban megjelenő írások a szerzők nézeteit tartalmazzák, ami nem feltétlenül egyezik a Magyar Nemzeti Bank hivatalos álláspontjával.

Szapáry György a Magyar Nemzeti Bank elnökének fötanácsadója. E-mail: szaparygy@mnb.hu

A magyar nyelvű kézirat első változata 2021. november 8-án érkezett szerkesztőségünkbe.

DOI: http://doi.org/10.25201/HSZ.20.4.120131 
egy újabb háborúhoz. A Schuman-nyilatkozatként híressé vált javaslat így kezdődött:

„A világbékét csak úgy lehet megörizni, ha az azt fenyegető veszélyekkel arányban álló kreativ erőfeszítéseket teszünk. Az, amivel egy jól szervezett és életteli Európa hozzá tud járulni a civilizációhoz, elengedhetetlenül szükséges a békés kapcsolatok fenntartásához. [...] Európát nem lehet egy csapásra felépíteni, sem pusztán valamely közös szerkezet kialakításával integrálni. Konkrét megvalósításokra, de mindenekelött a tényleges szolidaritás megteremtésére van szükség. Az európai nemzetek összefogásához szükség van arra, hogy Franciaország és Németország között megszünjen az évszázados ellentét."

Innen gyökerezik az a centripetális, összetartó erő, amely megalapozta, kísérte, előre vitte az európai integráció menetét a mára elért eredményekhez: a négy szabadság, azaz az áruk, a szolgáltatások, a tőke és a munkaerő szabad áramlása, a Schengeni övezet és a közös pénz létrehozása. Azonban az egyre szorosabbra füződő integrációt kikövező út sem volt konfliktusmentes. Gondoljunk az Egyesült Királyság Európai Gazdasági Közösséghez (az EU elődje) való csatlakozásánál de Gaulle francia elnök kétszeri vétójára, a francia „üres szék” politikára, amikor de Gaulle hat hónapon át bojkottálta a Tanács üléseit, valamint az euro bevezetése és a keleti bővítés körüli vitákra. Az „üres szék” politikájára azért érdemes visszaemlékezni, mert egy olyan fontos témához kapcsolódik, ami ma az egyik kiemelkedő centrifugális tényező: a szuverenitás pártiak és a föderalisták összecsapása. A francia bojkott megakadályozni kívánta a föderalisták kezdeményezését, hogy a Tanács többségi szavazással hozza meg döntéseit. Franciaország elérte, hogy a fontos témákban a döntéseket egyhangúan kelljen meghozni a Tanácsban, ez a mai napig érvényes gyakorlat. A téma viszont megint napirendre került, mert egyre több nyugat-európai ország kíván ezen változtatni, aminek egyik mozgatórúgója a keleti bővítésben gyökerezik. Erre a későbbekben részletesebben kitérek.

A négy szabadság biztosításával és a közös pénz bevezetésével a centripetális erők dominanciájának korszaka lezártnak tűnik, és új centrifugális erők léptek fel. Ahogy Kiran Klaus Patel (2021) is felhívja a figyelmet, már Jean Monnet is arról beszélt, hogy az európai integráció cikkcakkos útvesztőkön át halad előre, és minden válságot meg kell ragadni a további integráció erősítésére. Az utolsó másfél évtized nem szűkölködött válságokból. A 2007-2008-as nagy pénzügyi válság és a Covid19-válság felszínre hozott olyan problémákat, amelyekkel eddig nem kellett szembesülniük az immár 27, a Brexit előtt 28 tagországból álló Európai Uniónak. Philippe Aghion és szerzőtársai (2021:312) a kreatív rombolásáról szóló könyvükben többek között a kapitalizmus jövőjéről írnak. A gazdasági növekedés lassulása, a jövedelemelosztás

\footnotetext{
${ }^{1}$ A Schuman-nyilatkozat teljes szövege megtalálható az Európai Unió honlapján: https://europa.eu/europeanunion/about-eu/symbols/europe-day/schuman-declaration_hu. Letöltés ideje: 2021. november 9.
} 
egyenlőtlenségének rohamos növekedése, a klímaváltozás által keltett szorongás és a globalizáció előtérbe került problémái megkérdőjelezni látszanak a kapitalista gazdaság hatékonyságába vetett hitet. A kapitalizmusnak kétségkívül vannak hátrányai, képes pénzügyi válságokat okozni, bizonytalanná teszi a munkahelyek megtartását, nem tudja jól megoldani a jövedelemegyenlőtlenségeket. A szerző szerint a kapitalizmus egy identitáskrízis kereszttüzébe került. Ez elmondható az Európai Unióról is. Mivel az ígért jólét bekövetkezése bizonytalanná vált, az integrációhoz kapcsolódó politikai és társadalmi átalakulással szembeni ellenállás megerősödött, és a kompromisszumon alapuló nemzetközi együttmúködés létjogosultsága megkérdőjeleződött (Patel 2018:279).

Általánosságban is megállapítható, hogy a kezdeti összetartó erő, a béke fenntartása felhígult az évtizedek folyamán. A mai politikai döntéshozók és a lakosság nagy többségének számára a második világháború már távoli történelem. Csak példaként említem, Emmanuel Macron francia elnök 1977-ben született, 32 évvel a második világháború vége után. Ő egyébként elkötelezett vezető az Európai Unió erősítése iránt, de ez általánosságban nem mondható el minden országra, gondoljunk csak a Brexitre.

A keleti bővítés is új dimenziót hozott magával. A gyakran és jogosan hivatkozott 70 év béke, amit az EU Európában biztosított, máshogy cseng annak a száz millió embernek a fülében, akik ebből a 70 évből 40-et a szovjet megszállás alatt szenvedtek el, elszakítva attól a lehetőségtől, hogy szabadon, a demokráciát építve és gazdasági gyarapodással élhessenek úgy, mint a nyugat-európai emberek. A volt szovjet szatellitországok emberei jogosan büszkék arra, hogy szabadságukat saját maguk vívták ki különösebb nyugati segítség nélkül. Ráadásul Németország egyesítését egyes nyugat-európai országok eleinte aggódva nézték. Akkoriban élt még az a mondás, hogy „Németországot annyira szeretik, hogy kettőt akarnak belőle”. Ezzel szemben a volt szocialista országok lelkesen támogatták Németország újraegyesítését - hazánk ebben elismerten döntő szerepet játszott. Ahogy Helmut Kohl német kancellár mondta, az első téglát a berlini falból Magyarország ütötte ki. A szovjethatalom uralma alatt gyötrődő országok polgárai tudták, hogy Európában nem lesz tartós béke Németország egyesítése és a kelet-európai országoknak az Európai Unióba való integrálása nélkül.

Az európai identitás kérdésével számos szerző foglalkozott, például Martonyi János (2018), Trócsányi László (2021), Thierry Chopin (2018), Uğur Tekiner (2020), Janik Szabolcs (2021), hogy csak egy párat említsek a legfrissebb publikációk közül. A „közös identitás” kérdése áll a gondolkodás középpontjában, azaz hogyan párosul, egyeztethető össze a közös európai identitás a nemzeti identitással, és hogyan definiálható az utóbbi. Az európai identitásról való gondolkodás változott az idők folyamán az integráció előrehaladtával és a bővítési hullámok következtében. Máshogy gondolkodtak erről, amikor a közösség még csak a hat alapító tagországból állt, és 
máshogy manapság, a 27 tagországot magában foglaló Európai Unióban. Az alapító országok idején az európai identitás kérdése politikai szinten alig foglalkoztatta a döntéshozókat, és a civil társadalmat sem izgatta különösebben ez a kérdés, a figyelem a gazdasági integráció lépéseire összpontosult, az „európaiság” mint olyan nem volt vita tárgya, a nemzeti identitást senki nem kérdőjelezte meg. Az északi és déli bővítés már a középpontba helyezte ezt a kérdést, ami a tervezett európai alkotmány elbukásában és a lisszaboni szerződés körüli vitákban kristályosodott ki. A keleti bővítés, a Nyugattól 40 éven át elszakított országok integrálása felhevítette a vitát, ami, mint látni fogjuk, meghúzódik a centrifugális erők felszínre kerülése mögött is. Sose felejtsük el, hogy különfélék maradunk, miközben európaiak vagyunk, figyelmeztet Trócsányi (2021).

\section{Centrifugális erők megjelenése}

Az Európai Uniót ma megosztó kérdések jelentős részének a gyökerei visszavezethetők az említett válságok által felszínre hozott problémákra: eltérő növekedési és munkanélküliségi ráták, ami meghatározza a költségvetési rászorultságot; növekvő jövedelemkülönbségek, ami növeli a társadalmi feszültséget és elégedetlenséget, valamint eltérő egészségügyi rendszerek és a lakosság egészségügyi állapota, ami befolyásolja a járvány kezelését és lefutását. A fejlődő szegényebb országokban a válságok hatásai hatványozottan vannak jelen, amelyek, háborús környezettel párosulva, elindítottak egy tömeges bevándorlási hullámot. Ezek a tények mind szétfeszítő erőket indítottak be az Európai Unión belül, amelyek multidimenzionális jellegűek, és átívelnek a hagyományos Kelet-Nyugat vagy Észak-Dél ellentéteken. Négy széthúzó erőre szeretném felhívni a figyelmet: a migrációra, a költségvetési politikára, a külpolitikára és a szuverenitásra.

\subsection{Migráció}

Az illegális tömegmigráció manapság az egyik legsúlyosabb megosztó tényező. A különböző történelmi tapasztalatok ebben fontos szerepet játszanak. A gyarmatosító országok hozzáállását a távolról jött bevándorlók befogadása iránt évszázados tapasztalatok formálták. A nyugat-európai országok túlnyomó többségének voltak gyarmatai: az Egyesült Királyságnak, Franciaországnak, Spanyolországnak, Portugáliának, Belgiumnak, Hollandiának, Olaszországnak, és az első világháború előtt Németországnak is. Ezeknek az országoknak alkalmuk volt megismerkedni gyarmataik lakóival, kultúrájukkal. A bevándorlók elsősorban a volt gyarmatokból jöttek, először a képzettebbek, akik már beszélték a gyarmatosító ország nyelvét, utána a kevésbé képzettek, de a folyamat fokozatos volt, és a lakosságnak volt ideje hozzászokni a betelepülők jelenlétéhez. Ráadásul sok Dél-Ázsiából, Dél-Kelet Ázsiából és Afrikából jött bevándorló vagy leszármazottjaik kivívták a befogadó nemzet elismerését az üzleti életben, sportban, zenében, irodalomban, még a politikában is 
elértek magas vezetői pozíciót. Ma már ez a folyamat sem feszültségmentes a tömeges bevándorlás elindulásával a múlt évtizedben. Mégis azon országok, amelyek gyarmatokkal rendelkeztek, „,befogadóbb” álláspontot képviselnek, ebben a történelmi tapasztalatokon túl talán a gyarmatosítók felelősségtudata is szerepet játszik.

Ezzel szemben a közép-kelet-európai országoknak nem voltak gyarmataik, népességük nem keveredett távolról jött bevándorlókkal, nem volt tapasztalatuk fokozatosan megismerkedni gyökeresen más kultúrákkal, viszont hirtelen szembesülniük kellett a határaikon áttörő vagy áttörni szándékozó hatalmas bevándorló tömegekkel. Természetszerǔen ellenállnak ennek, mint látjuk, már nemcsak Magyarország, hanem Lengyelország és a balti országok is határvédő kerítés építésébe kezdtek. Ez megosztja az EU közösségét, mert a gazdagabb gyarmatosító országok, ahová a bevándorlók el szeretnének jutni, a migránsok kötelező elosztását szorgalmazzák az EU-tagországok között. A kerítések tulajdonképpen a gazdagabb nyugat-európai országokat védik. A tengerparttal rendelkező országok is szorgalmazzák az elosztást, mert nehezebb és humanitárius szempontból is kényesebb a bevándorlókat a tengeren feltartóztatni, mint a szárazföldi utakon, amit egyébként a migránsok preferálnak, mert biztonságosabb. Tehát a tömeges migráció kezelése olyan centrifugális erőt képez, ami a történelmi tapasztalatok eltérő mivoltában gyökerezik, és amihez jelentősen hozzájárul a nyugat- és kelet-európai országok közötti életszínvonal-különbség is. A háborúskodás és az afrikai kontinensen a klímaváltozás okozta elterjedő szárazság miatt útra kelő emberek tömeges megjelenése Európa határainál még hosszú éveken át kiemelkedő megosztó témaként lesz jelen az Európai Unió politikai vitáiban. Európa gazdag és védtelennek mutatkozik, ami vonzóvá teszi kontinensünket a szegényebb országok bevándorlói számára.

\subsection{Költségvetési politika}

Az Európai Unió kohézióját feszítik, fenyegetik a nagy különbségek a munkanélküliségi ráták és a költségvetési mozgástér terén. Az eurozóna átlagos munkanélküliségi rátája 8 százalék, de például Görögországban és Spanyolországban a ráta kb. 16 százalék² (IMF 2021). Míg 2007-ben az államadósság mindössze hat országban haladta meg szignifikánsan a GDP 60 százalékát jelentő maastrichti kritériumot, addig 2021-re az előrejelzések szerint 14 ország fogja átlépni ezt a szintet. Viszont itt is nagyok a különbségek: az eurozóna átlaga a GDP 100 százaléka, de pontosan azokban az országokban, ahol nagy a munkanélküliség, mint Görögország, Spanyolország és Olaszország, az államadósság nagymértékben meghaladja ezt, Görögországban például a 200 százalékot is (IMF 2021) 3 $^{3}$ Az egységes monetáris politikához tartoznia kellene valamilyen szinten egy közös költségvetési politikának, de ilyen nincs, csak fiskális szabályok, amiket többnyire nem tartottak be. Az erre vonatkozó

2 előrejelzés a 2021-es évre

3 előrejelzés a 2021-es évre 
szabályokban könnyű kivételeteket találni, hivatkozva az eltérő körülményekre és évekig a túlzott deficit eljárás alatt álló országok büntetésfizetésének elengedésére. Ismét napirendre került ezeknek a szabályoknak az esetleges megváltoztatása.

Ha lenne egy fiskális unió, aminek létrehozatala egyelőre az utópia tartományába sorolható, akkor az automatikus stabilizátorok részben kezelni tudnák a munkanélküliségi ráták különbségéből származó problémákat, és az elkerülhetetlen megszorító intézkedéseket enyhíteni lehetne, mert teret adna anticiklikus fiskális politika alkalmazására. Így viszont szükség van mankóra, külső segítségre. Itt tetten érhető egy másik centrifugális erő, az újra előtérbe került Észak-Dél érdekütközés, aminek félreérthetetlen jele a „fukar négy” (Ausztria, Hollandia, Svédország, Dánia) követelése és sikere, hogy megnöveljék a hitelek részét a vissza nem térítendő összegek rovására az Európai helyreállítási terv, a Next Generation EU forrásainak kedvezményezettjei számára. Ez világos jele annak, hogy a gazdagabb és szegényebb országok közötti érdekkonfliktus a jövőben is kísérni fogja az EU integrációs törekvéseit. Ez akadályozza, illetve lassítja az olyan további lépéseket a gazdasági integrációt erősítő úton, mint például az európai bankbetét-biztosítási rendszer létrehozása vagy a bankszanálási alap feltöltése, mivel a gazdagabb országok, föleg Németország, tartanak attól, hogy nekik kell majd finanszírozni más országok bankjainak veszteségeit. A gazdagabb országok a kockázatok csökkentését hangsúlyozzák, más országok a kockázatok porlasztásában érdekeltek. Bár a helyreállítási alapnak van egy újraelosztási szerepe, amennyiben arányosan több pénz jut azoknak az országoknak, amelyek a járvány miatt többet szenvedtek, de amint láthatjuk, ez éppen oda vezetett, hogy kihegyezze a gazdagabb-szegényebb országok közötti érdekkülönbséget.

Az eredeti javaslat az volt, hogy a 750 milliárd euro helyreállítási alapból 500 milliárd eurót vissza nem térítendő juttatásként bocsássák a jogosult tagországok részére, és 250 milliárd eurót kölcsönként. A „fukar négy” elérte, hogy ez az arány 390-360 milliárd euróra módosuljon, ami jelentős változás az eredeti javaslathoz képes. Újdonság, hogy a tagállamok közösen vállalnak garanciát a 750 milliárd euro (2018-as árakon) kölcsönért, amit a Bizottság fog felvenni a piacokról. Magyarország folyóáron 8,6 milliárd euro vissza nem térítendő ${ }^{4}$ és 9,7 milliárd euro kölcsönre jogosult a Next Generation EU helyreállítási alapból. Az EU 2021-2027-es hétéves költségvetési keretéből, amely a Brexit miatt már eleve kisebb, mint az előző hétéves keret, Magyarország számára a kohéziós alapból befolyó összeg mértéke csökken (1. ábra), mert a kohéziós forrásokat meghatározó képlet változott azon országok javára, ahol a szegényebb régiók egy főre jutó jövedelme alacsony. Több tagország is van, ahol a szegényebb régiókban az egy före jutó jövedelem alacsonyabb a magyar átlagnál.

4 7,2 milliárd euro a Recovery and Resilience Facility (RRF) alapból és 1,4 milliárd euro egyéb alapokból. MNB-számítás az EU-Bizottság adatai alapján. 


\section{1. ábra \\ Támogatások a 2014-2020 és 2021-2027 EU-s költségvetési keretből (a GDP százalékában)}

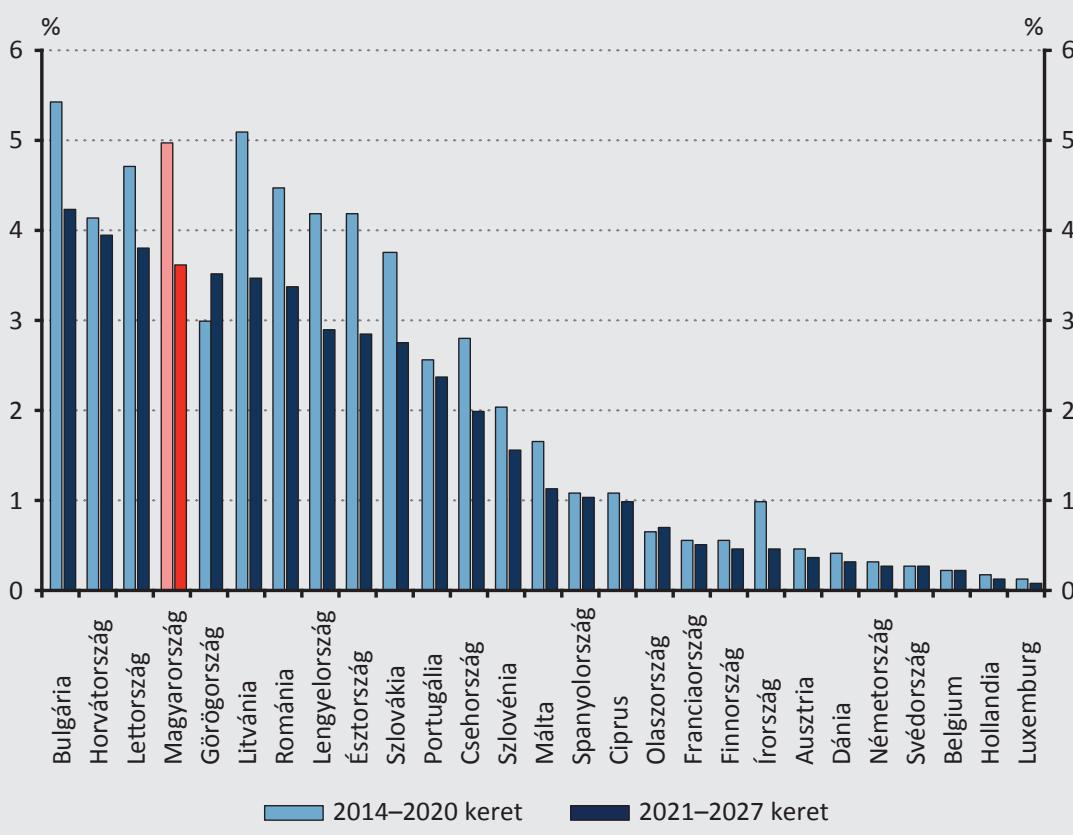

Megjegyzés: A 2013. és a 2020. évi GDP arányában, éves átlaggal számolva. Tartalmazza a kohéziós forrásokat és a Közös Agrárpolitikai alapokat. A Next Generation EU forrásait nem tartalmazza.

Forrás: MNB-számítás az Európai Bizottság adatai alapján

Érdemes egy pillantásra visszatérni az államadósság témájához. Nem vitatott, hogy a válságok kezeléséhez szükség volt és még továbbra is szükséges lehet a költségvetési kiadások növeléséhez a munkahelyek megőrzése, a munkanélküliség enyhítése és a járvány leküzdése érdekében. Természetesen ez az államadósságok megugrásához vezetett. Egyes neves közgazdászok körében (lásd pl. Blanchard 2019) az a tétel kezdett elterjedni, hogy az államadósság már nem is olyan fontos kérdés a fejlett országokban, mert strukturális okok következtében megfigyelhető egy több évtizedes trend, miszerint az állami kötvényekre fizetett hosszú távú nominális kamatok csökkennek (2. ábra). Ezen közgazdászok azon a véleményen vannak, hogy még a pesszimista szcenáriók szerint is a GDP növekedése a fejlett országokban ezt az alacsony kamatszintet trendszerúen meg fogja haladni, s így az államadósság magától el fog olvadni (Szapáry - Hardi 2021). 


\section{2. ábra}

10 éves államkötvény nominális hozama (1981-2020, 5 éves átlag, százalékban)

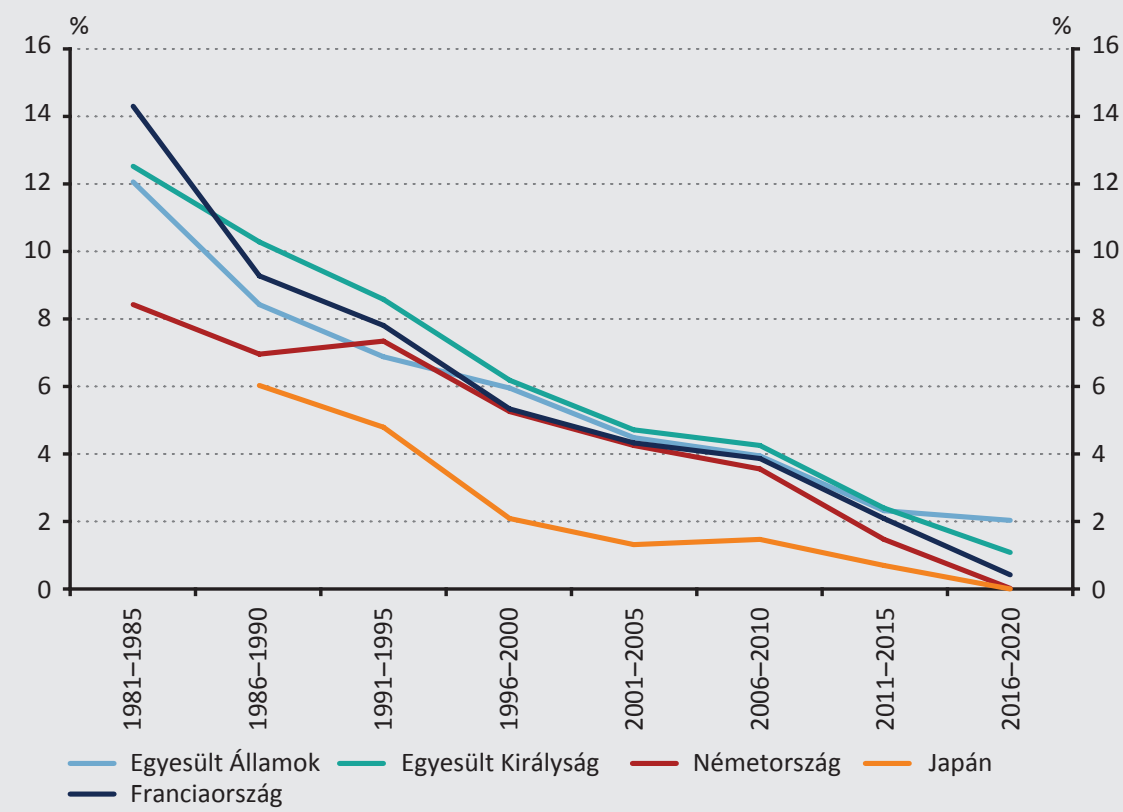

Forrás: Federal Reserve Economic Data (FRED)

Matematikailag ez igaz állítás, de azt feltételezni, hogy a megfigyelt trend mindig így fog folytatódni a jövőben, veszélyes. A kamatok alakulása ugyanis eltérhet a trendtől, ha a bizalom egy ország fizetóképességében megrendül, pont a magas államadósság vagy a fizetésimérleg-hiány miatt. Erre számos példa van. Egy másik neves közgazdászt idézve, a pénzügyi világ veszélyessé válhat, ha a kormányok elhiszik, hogy egy csodaországban élnek, ahol a fiskális kényszer nem érvényesül (Wyplosz 2019).

\subsection{Külpolitika}

Az Európai Unió külpolitikáját tekintve Oroszország és Kína felé megosztott. A krími félsziget annektálásával és katonai beavatkozásával Kelet-Ukrajnában Oroszország szembetalálta magát a NATO ellenállásával. Következésképpen az Európai Unió szankciókat vetett ki Oroszországgal szemben, amit a tagországok egyhangúan támogattak. Ennek ellenére komoly nézetkülönbségek alakultak ki az Európai Unión belül. Lengyelország és a balti államok, amelyeknek közös határuk van Oroszországgal, és talán még azt is mondhatjuk, hogy a többi szocialista országgal szemben gyötrelmesebb tapasztalatokkal rendelkeznek a Szovjetunióval kapcsolatban, kemény fellépést várnak el az EU részéről. Ez az álláspont termékeny talajra lel egyes nyugati országokban, bár nem ambivalenciamentesen, ha figyelembe vesszük az Északi Áramlat-2 
beruházásának érthető módon hathatós támogatását Németország részéről. Németország ugyan nemrég felfüggesztette a gázszállítás engedélyezését, de csak átmentileg. Magyarország árnyaltabb politikát folytat Oroszországgal szemben. Mi megtapasztaltuk, hogy amikor a nagyhatalmak a fejünk felett összecsapnak, annak elszenvedő alanyai vagyunk. Ráadásul a gázellátásunk is Oroszországtól függ, miközben keressük a források diverzifikációját. Magyarország egy kölcsönös tiszteletben tartás logikája mentén alakítja ki politikáját Oroszország viszonyában. Ez váltotta ki egyes nyugat-európai politikusok szemében azt a nézetet, hogy Magyarország Putyin trójai falova az Európai Unióban. Ez a narratíva, hasonlóan a tömeges migrációhoz való viszonyuláshoz, csak szítja a Nyugat-Kelet ellentéteket, erősíti a széthúzó erőket.

Kínával szemben az EU-nak vannak jogos sérelmei. A reciprocitás hiánya a kereskedelemben és a beruházásokban, valamint a szellemi tulajdon védelmének hetyke kezelése komoly kritikákat váltott ki az Európai Bizottság és egyes nagy nyugat-európai tagországok részéről. $A$ közép-kelet-európai országok próbálják minél jobban kihasználni a nyugati országokhoz képest még gyerekcipőben járó kereskedelmi és beruházási lehetőségeket Kínával. Az Egy Övezet Egy út és a 16+1 (Litvánia nemrég kilépett) kínai kezdeményezésekre gyanakvóan tekintenek a nyugati EU-tagországok, azt sugallva, hogy a volt szocialista országok megágyazzák Kína politikai befolyását Európában. Ez a vélekedés valószínűleg erősödni fog, ahogy a kereskedelmi, befektetési, tudományos és kulturális kapcsolatok intenzívebbé válnak több közép-kelet-európai országgal. A nyugat-európai országok ebben az esetben is megosztó magatartást tanúsítanak, figyelembe véve, hogy a kereskedelmi forgalom és a beruházási tevékenységek Kína és Nyugat-Európa között messze meghaladják a kelet-európai országokét.

\subsection{Szuverenitás}

A szuverenitás versus föderalizmus a legvitatottabb kérdés. Már de Gaulle idejében is kulcsfontosságú volt. A Brexitet is ez a téma fütötte, a global Britain a szuverenitás teljes mértékű visszaszerzését vizionálta. Mondhatnánk, hogy ez a legjelentősebb centrifugális erő, ami, mint egy alvó vulkán, alkalomadtán a felszínre tör, és lávájával olyan sérüléseket okoz a környezetében, amelyek hatását nehéz előre megbecsülni. Napjainkban a jogállamiság helyzete Lengyelországban és Magyarországon borzolja a kedélyeket. Mindkét ország azt vallja, hogy az Európai Unió a szervein keresztül olyan kérdésekben akar döntést hozni, amelyeket a tagországok nem ruháztak át az Európai Unióra. Ilyen például a tömeges bevándorlás, ami megváltoztatná a népesség kulturális és vallási összetételét, vagy a család védelme. Még nem tudni, hogy mi lesz ennek a végkimenete, de itt érdemes egy pillanatra megállni. Bár a múltban más országok, nem kevésbé Németország is, kiálltak az alkotmányos identitás sérthetetlensége mellett, és vitatták az európai jog feltétlen és korlátok nélküli elsőbbségét a tagország jogrendszere felett, a fent említett két esetben ismét kitapintható egy Kelet-Nyugat közötti nézetkülönbség. Több oka is van annak, hogy 
Európa keleti térfelének egy részén aggállyal tekintenek Brüsszel növekvő beleszólására olyan témákba, amelyeket a tagország a saját belügyének tekint, és amelyeket véleményük szerint nem ruháztak át az Unió hatáskörébe. Egyfelől a kelet-európai országok nem voltak, nem lehettek ott az alapok lefektetésénél, nem vettek részt az ezt övező vitákon, már csak a lisszaboni szerződés megszületésén lehettek jelen, de ez a szerződés nem volt előzmények nélküli. Másfelől az aggályokat erősítik a rossz tapasztalatok Moszkva uralma alatt. Végül a gyors jólét, amivel az európai uniós tagság kecsegtetett, elmaradt, ami szintén növelheti az ellenállást Brüsszellel szemben. Ezek statisztikailag nem mérhető érzések, viszont befolyásolják a politikusok gondolkodását annak ellenére, hogy a kelet-európai népek többsége az EU-ban látja a jövőjét. Az se segíti a kelet-nyugati összefogást, amikor olyan kijelentések hagyják el befolyásos nyugati politikus száját egyes kelet-európai országok irányába, hogy az Európai Unió nem egy ATM, vagy hogy térdre kell kényszeríteni Magyarországot. Ismert, hogy az ilyen kijelentések legtöbbször az adott politikusok saját lakosságához szólnak, de azért érdemes ezeket a megszólalásokat feleleveníteni, mert rámutatnak egy fontos centrifugális tényezőre, nevezetesen, a kelet-európai országokat ki lehet, ki kell oktatni.

Nem lesz erős, egységes Európai Unió, ha az új tagországokat nem tekintik egyenrangúnak. Az egyre szorosabb Európa (ever closer Europe) nem valósítható meg a tagországok és polgáraik beleegyezése nélkül. Egység a különbségben, szokták hangoztatni, de a különbségeket nem mindig értik meg vagy fogadják el jó szívvel. Egy nemzet nemcsak a nyelvében, hanem történelmében és kultúrájában is él. A kelet-európaiak curriculumához tartozik Nyugat-Európa történelmének ismerete. Személyes tapasztalatom, hogy Nyugaton vajmi keveset tudnak - mondjuk - Magyarország, Románia, Bulgária, Horvátország történelméről, népességének összetételéről.

Ismét előtérbe került a kérdés, hogy a szövetségi vagy a szuverén nemzetállamokra épülő struktúra a legjobb út a szorosabb és szolidárisabb demokratikus európai integráció felé. Véleményem szerint a nemzetállamok (nation states) nem veszélyeztetik ezt a törekvést. Ellenkezőleg, a 20. századi európai felszabadító háborúk és a kommunista diktatúrával való szembenállás a tanulsága annak, hogy erős európai nemzetállamok az eddig kitalált legjobb egység, közösség, ami meg tudja teremteni a bizalmat és áldozatkészséget a szabadság és a demokrácia védelmére. A francia ellenállók és a szövetségesek oldalán harcoló lengyel katonák a második világháború idején mint hazájukhoz hűséges franciák és lengyelek haltak hősi halált. Az 1956-os forradalomban és szabadságharcban felkelő emberek is mint magyar hazafiak az ország függetlenségért harcoltak. Ezek a példák jól tanúsítják a nemzeti identitás erősségét. Csak erős és dinamikusan fejlődő nemzetállamok garantálhatnak erős Európai Uniót. 


\section{Hogyan tovább?}

A legfontosabb és legnépszerúbb integrációs lépések már a hátunk mögött vannak: az egységes piac, Schengen, a közös pénz. Még hátravannak azonban fontos lépések, amelyek erősítenék a gazdasági integrációt és az Európai Unió ellenálló képességét a jövő válságaival szemben, továbbá a felkészültségét is az új kihívásokra: a bankunió befejezése, a szolgáltatások és tőkepiacok további liberalizációja, a fiskális politikák reálisabb alapon való összehangolása az eurozónán belül, a klímaváltozás kezelése. Meg kell célozni a szorosabb együttmüködést a kutatásban és oktatásban és, horribile dictu, a külpolitikában is. Kína felemelkedésével és Amerika geopolitikai befolyásának látható visszaszorulásával, valamint stratégiai figyelmének Ázsia felé fordulásával csak egy erős és összetartóbb Európa tudja megtartani versenyképességét és befolyását a kialakuló új világrendben (Szapáry - Plósz 2019). Megújult a szándék, hogy az Unió egy gyorsan bevethető hadsereget állítson fel. Noha évtizedeken át kiemelt kérdés volt a közös védelmi politika, az érdekkülönbségek mindeddig megakadályozták egy európai harci egység létrehozását, amihez vélhetően a német „Schuldkult” (nemzeti bűntudat) is hozzájárulhatott. A geopolitikai változások remélhetőleg meggyőzik a politikusokat Európa védelmi képességének erősítésére.

Európában kétségtelenül van egy szoros összetartó erő, ami a gazdasági érdekeken túl a közös, bár viharos történelemben és a keresztény alapokon nyugvó társadalom összetételében gyökeredzik. Azonban az újonnan felszínre tört és fent taglalt széthúzó erők sajnos elvonják a figyelmet a szükséges reformokról, és felemésztik a kivitelezésükhöz szükséges energiát. Viták mindig voltak és mindig is lesznek egy olyan közösségben, mint az Európai Unió, amelynek tagországai különböző nyelvekkel és kultúrával és részben eltérő történelemmel is rendelkeznek. Erős Európához annyi kell, hogy minden tagország ezeket a különbségeket elfogadja és tiszteletben tartsa. Ismert, hogy Németország és Franciaország az európai integráció motorja, az ő szoros szövetségük nélkül az európai projekt nem halad előre. Nem lehet erős, egységes Európa a közép-kelet-európai országok teljes körü egyenrangúságának elismerése nélkül sem, ami a közös gondolkodásban és egymást történelmének és kultúrájának kölcsönös megismerésén nyugszik. Ahogy Martonyi János (2018:109), Magyarország volt külügyminisztere fogalmaz: „Közép-Európa vitathatatlanul Európa része... Közép-Európa egy intenzívebb, sürübb Európa. Egy magasabb fordulatszámmal rendelkező Európa.”. Henri Bergson francia filozófust idézve: „A jövő nem az, ami be fog következni, hanem az, amit tenni fogunk".

\section{Felhasznált irodalom}

Aghion, P. - Antonin, C. - Bunel, S. (2021): The Power of Creative Destruction: Economic Upheaval and the Wealth of Nations. Harvard University Press, Cambridge, Massachusetts and London, England. https://doi.org/10.4159/9780674258686 
Blanchard, O. (2019): Public Debt and Low Interest Rates. American Economic Review, 109(4): 1197-1229 https://doi.org/10.1257/aer.109.4.1197

Chopin, T. (2018): Europe and the identity challenge: who are "we"? Fondation Robert Schuman, European Issues No. 466, 19 March. https://www.robert-schuman.eu/en/doc/ questions-d-europe/qe-466-en.pdf. Letöltés ideje: 2021. november 9.

IMF (2021): World Economic Outlook - Recovery During a Pandemic. Health Concerns, Supply Disruptions, and Price Pressures. October, 2021... https://www.imf.org/en/Publications/ WEO/Issues/2021/10/12/world-economic-outlook-october-2021\#: :text=The\%20 global\%20economy\%20is\%20projected,than\%20in\%20the\%20July\%20forecast. Letöltés ideje: 2021. november 9.

Janik Szabolcs (2021): New Hungarian V4 Presidency: Opportunities and Challenges. Hungarian Conservative, 1(3): 12-15. https://www.hungarianconservative.com/articles/ politics/new-hungarian-v4-presidency-opportunities-and-challenges/. Letöltés ideje: 2021. november 9.

Martonyi János (2018): Merre tovább Európa? Közép-Európa Újjászületése. Megjelent: Martonyi János: Nyitás és identitás: Geopolitika, világkereskedelem, Európa. Iurisperitus Kiadó, Szeged, pp. 108-169. http://acta.bibl.u-szeged.hu/68973/1/polay_070.pdf. Letöltés ideje: 2021. november 9.

Patel, K.K. (2018): Project Europe: A History. Cambridge University Press, United Kingdom.

Szapáry György - Hardi Zsuzsanna (2021): Maradandó vendég a magas államadósság? Szakmai cikk, Magyar Nemzeti Bank. https://www.mnb.hu/letoltes/szaparygyorgy-hardi-zsuzsanna-maradando-vendeg-a-magas-allamadossag.pdf. Letöltés ideje: 2021. november 9.

Szapáry György - Plósz Dániel János (2019): Geopolitikai irányváltások a kialakulóban lévő új világrendben. Hitelintézeti Szemle, 18(4): 112-129. http://doi.org/10.25201/ HSZ.18.4.112129

Tekiner, U. (2020): The 'European (Union) Identity': An overview. E-International Relations, 15 April. https://www.e-ir.info/2020/04/15/the-european-union-identity-an-overview/ Letöltés ideje: 2021. november 9.

Trócsányi László (2021): The Future of Europe. Hungarian Review, 12(1): 8-18 https:// hungarianreview.com/article/20210324_the_future_of_europe/

Wyplosz, Ch. (2019): Olivier in Wonderland. VoxEU, 17 June. https://voxeu.org/content/ olivier-wonderland. Letöltés ideje: 2021. november 9. 